\title{
Estimating the viral loads of SARS-CoV-2 in the oral cavity when complicated with periapical lesions
}

\author{
Alaa Muayad Altaie ${ }^{1}$, Rania Hamdy ${ }^{1}$, Thenmozhi Venkatachalam ${ }^{1,2}$, Rifat Hamoudi ${ }^{1,3+}$ and \\ Sameh S. M. Soliman ${ }^{1,4^{*}+}$
}

\begin{abstract}
Background: The oral cavity represents a main entrance of the severe acute respiratory syndrome coronavirus-2 (SARS-CoV-2). Angiotensin-converting enzyme 2 (ACE-2), neuropilin-1 (NRP-1), and transmembrane serine protease 2 (TMPRSS2) are essential for the entry of SARS-CoV-2 to the host cells. Both ACE-2 and NRP-1 receptors and TMPRSS2 have been identified in the oral cavity. However, there is limited knowledge about the impact of periapical lesions and their metabolites on the expression of these critical genes. This study aims to measure the impact of periapical lesions and their unique fatty acids (FAs) metabolites on the expression of the aforementioned genes, in addition to interleukin 6 (IL-6) gene and hence SARS-CoV-2 infection loads can be estimated.
\end{abstract}

Methods: Gene expression of ACE-2, NRP-1, TMPRSS2, and IL-6 was performed in periapical lesions in comparison to healthy oral cavity. Since FAs are important immunomodulators required for the lipid synthesis essential for receptors synthesis and viral replication, comparative FAs profiling was determined in oral lesions and healthy pulp tissues using gas chromatography-mass spectrometry (GC-MS). The effect of major identified and unique FAs was tested on mammalian cells known to express ACE-2, NRP-1, and TMPRSS2 genes.

Results: Gene expression analysis indicated that ACE-2, NRP-1, and TMPRSS2 were significantly upregulated in healthy clinical samples compared to oral lesions, while the reverse was true with IL-6 gene expression. Saturated and monounsaturated FAs were the major identified shared and unique FAs, respectively. Major shared FAs included palmitic, stearic and myristic acids with the highest percentage in the healthy oral cavity, while unique FAs included 17-octadecynoic acid in periapical abscess, petroselinic acid and L-lactic acid in periapical granuloma, and 1-nonadecene in the radicular cyst. Computational prediction showed that the binding affinity of identified FAs to ACE-2, TMPRSS2 and S protein were insignificant. Further, FA-treated mammalian cells showed significant overexpression of ACE-2, NRP-1 and TMPRSS2 genes except with L-lactic acid and oleic acid caused downregulation of NRP-1 gene, while 17-octadecynoic acid caused insignificant effect.

Conclusion: Collectively, a healthy oral cavity is more susceptible to viral infection when compared to that complicated with periapical lesions. FAs play important role in viral infection and their balance can affect the viral loads. Shifting the balance towards higher levels of palmitic, stearic and 1-nonadecene caused significant upregulation of

\footnotetext{
*Correspondence: ssoliman@sharjah.ac.ae

${ }^{\dagger}$ Rifat Hamoudi and Sameh S. M. Soliman share equal senior co-

authorship

${ }^{1}$ Research Institute of Medical and Health Sciences, University of Sharjah,

Sharjah, UAE

Full list of author information is available at the end of the article
}

(C) The Author(s) 2021. Open Access This article is licensed under a Creative Commons Attribution 4.0 International License, which permits use, sharing, adaptation, distribution and reproduction in any medium or format, as long as you give appropriate credit to the original author(s) and the source, provide a link to the Creative Commons licence, and indicate if changes were made. The images or other third party material in this article are included in the article's Creative Commons licence, unless indicated otherwise in a credit line to the material. If material is not included in the article's Creative Commons licence and your intended use is not permitted by statutory regulation or exceeds the permitted use, you will need to obtain permission directly from the copyright holder. To view a copy of this licence, visit http://creativecommons.org/licenses/by/4.0/. The Creative Commons Public Domain Dedication waiver (http://creativeco mmons.org/publicdomain/zero/1.0/) applies to the data made available in this article, unless otherwise stated in a credit line to the data. 
the aforementioned genes and hence higher viral loads. On the other hand, there is a reverse correlation between inflammation and expression of SARS-CoV-2 receptors. Therefore, a mouth preparation that can reduce the levels of palmitic, stearic and 1-nonadecene, while maintaining an immunomodulatory effect can be employed as a future protection strategy against viral infection.

Keywords: Oral lesions, Fatty acids, SARS-CoV-2, COVID-19, Infection load, Oleic acid

\section{Background}

Coronavirus disease 2019 (COVID-19) outbreak caused by severe acute respiratory syndrome coronavirus-2 (SARS-CoV-2) is a global threat [1]. Oral cavity is considered as an important entry port for the virus [2]. Since COVID-19 seems to stay for longer time, the relationship between oral health and SARS-CoV-2 infection could provide important information to help on making a managing decision related to this contagious disease. On the other hand, the complications of SARS-CoV-2 infection by pathological conditions at the oral cavity such as periapical lesions have never been reported. Viral infection loads via the oral cavity are significantly controlled by the expression of cell membrane binding receptors and host proteases. Studies highlighted the expression of angiotensin-converting enzyme 2 (ACE-2) in the oral mucosa, tongue [3, 4], buccal, gingival tissues [4], in addition to the normal and inflamed dental pulp [5]. Besides, several studies have demonstrated the role of neuropilin-1 (NRP1) as a receptor for SARS-CoV-2 infection [6-8]. NRP-1 receptor localized to the outer supra-basal epithelial layers of the normal tongue [9] and plays indispensable roles in wound healing, angiogenesis, bone formation, teeth formation [10-13], and odontoblastic differentiation of dental pulp stem cells [14]. Human host proteases particularly transmembrane serine protease 2 (TMPRSS2) enzyme is essential for the activation of SARS-CoV-2 S protein in human airway epithelial cells [15]. TMPRSS2 is highly expressed in oral stratified squamous epithelium, saliva, and tongue tissues [16].

Metabolites of the human body particularly FAs also play an important role in viral infection $[17,18]$. Some metabolites present in the human body play a protective role against viral infection including SARS-CoV-2 [19], while others worsen the condition [20]. Metabolites profile in pathological conditions is different than in healthy conditions. These metabolites can develop a microenvironment that may affect the viral infection. Here in this study, the expression of ACE-2, NRP-1, and TMPRSS2 genes in association with FAs microenvironment were investigated in periapical lesions compared to healthy pulp tissues. The effects of both the expression of the aforementioned genes and the FAs microenvironment on SARS-CoV-2 infection load in the oral cavity were then estimated.

\section{Methods}

\section{Cell culture and metabolites}

Human embryonic kidney (HEK293) cells were purchased from (ATCC ${ }^{\circledR}$ CRL1573 $^{\mathrm{TM}}$, USA) and cultured in Dulbecco's Modified Eagle Medium/Nutrient Mixture F-12 (DMEM/F-12) (Sigma-D8437, Germany), supplemented with FBS (Sigma, Germany), and penicillin-streptomycin (Sigma, Germany). HEK293 cells were employed as model cells that normally express both ACE-2 and NRP-1 receptors and TMPRSS2 enzyme and related to high comorbidity in SARS-CoV-2 infection. The purchased metabolites were palmitic acid (Sigma Aldrich, Germany), stearic acid (Sigma Aldrich, Germany), oleic acid (Daejung, Korea), 17-octadecynoic acid (Santa Cruz, USA), 1-nonadecene (TCI, US-Japan), and L-lactic acid (Sigma Aldrich, Germany).

\section{Sample's collection}

This study includes 40 samples of 28 males and 12 females with an age range of 15-60-year-old. The samples were 10 periapical abscesses, 10 preapical granulomas, 10 radicular cysts, and 10 healthy pulp tissues, employed as healthy control. For all periapical lesions, the general inclusion criteria included carious lesion, necrotic pulps, evidence of periradicular radiolucency and bone loss, in addition to facial pain and swelling in cases of periapical abscess [21]. The exclusion criteria included systemic diseases, history of corticosteroid treatment, pregnancy, radiotherapy, tooth mobility, and vertical tooth fracture. The sampling procedure was performed as previously described [22, 23]. Periapical lesions were isolated from the root tips using sterile surgical scalpel blade No.11. Healthy pulp tissue samples were collected after surgical extraction of impacted wisdom teeth and as previously described [24, 25].

The collected samples were confirmed by standard histopathology procedure following fixation in $10 \%$ neutral buffered formalin for at least $24 \mathrm{~h}$ and subsequent embedding in paraffin wax. The histopathological structure of the lesions was assessed by traditional haematoxylin and eosin staining for optical microscope examination. Periapical granulomas and radicular cysts were differentiated according to the absence or the presence of a clear cavity lined by epithelium [26]. 
Fatty acids (FAs) profiling in oral lesions

Compared to healthy control, FA metabolites profiling in oral lesions were identified following a previously described method $[27,28]$. Briefly, frozen tissues were suspended in methanol: chloroform (1:1) followed by sonication in a sonicator water bath for $1 \mathrm{~h}$ at room temperature. The filtered extracts were derivatized and analyzed by $\mathrm{GC}-\mathrm{MS}$ following protocol established by Soliman et al., 2020 [27]. The metabolite extracts were derivatized by mixture of $N$-Trimethylsilyl- $N$-methyl trifluoroacetamide and Trimethylchlorosilane (MSTFA $+1 \%$ TMS) and analyzed by GC-MS using QP2010 gas chromatography-mass spectrometer (GC-2010 coupled with a GC-MS QP-2010 Ultra) equipped with an auto-sampler (AOC-20i + s) from Shimadzu (Tokyo, Japan), using Rtx-5 ms column (30 m length $\times 0.25 \mathrm{~mm}$ inner diameter $\times 0.25 \mu \mathrm{m}$ film thickness: Restek, Bellefonte, PA). FAs data were extracted from the metabolites list identified using NIST library. The average \% amount of each metabolite was identified in relation to other metabolites per sample. Fold difference of each metabolite in relation to healthy control was displayed. A comprehensive search was performed to correlate the identified FA to viral infection particularly those related to coronavirus including COVID-19 infection (Table 1).

\section{Calculation of FA protein binding affinity}

The 3D structures of the selected FAs were downloaded as SDF file from PubChem database, followed by energy minimization and saved as PDBQT format. The 3D crystal structures of proteins were downloaded from Protein Data Bank (PDB) (http://www.rcsb.org). The proteins were prepared, and hydrogen was added, while water, ligand and hetero ions were removed. The proteins were converted to macromolecules PDBQT format with Chimera software before docking. The binding affinity of FAs with the target proteins was calculated using Pyrx Autodock binding engines. The acids metabolites were docked within the binding site of the ACE-2 (PDB:1R4L),

Table 1 Metabolite microenvironment of oral lesions in relation to viral infection particularly coronavirus including SARS-CoV-2

\begin{tabular}{|c|c|c|c|c|c|c|c|c|c|}
\hline \multirow[t]{3}{*}{ Metabolite } & \multirow[t]{3}{*}{ Class } & \multicolumn{4}{|c|}{ Detected levels of metabolites in oral cavity } & \multirow{3}{*}{$\begin{array}{l}\text { Reported } \\
\text { levels of } \\
\text { metabolites } \\
\text { during } \\
\text { coronavirus } \\
\text { infection }\end{array}$} & \multirow{3}{*}{$\begin{array}{l}\text { Reported } \\
\text { effect of } \\
\text { metabolites } \\
\text { on } \\
\text { coronavirus } \\
\text { infection }\end{array}$} & \multirow{3}{*}{$\begin{array}{l}\text { Reported } \\
\text { antiviral } \\
\text { activity of } \\
\text { metabolites }\end{array}$} & \multirow{3}{*}{$\begin{array}{l}\text { Reported } \\
\text { effect of } \\
\text { metabolites } \\
\text { on IL-6 }\end{array}$} \\
\hline & & \multicolumn{3}{|c|}{ Oral lesions } & \multirow{2}{*}{$\begin{array}{l}\text { Healthy } \\
\text { control }\end{array}$} & & & & \\
\hline & & $\begin{array}{l}\text { Periapical } \\
\text { abscess }\end{array}$ & $\begin{array}{l}\text { Periapical } \\
\text { granuloma }\end{array}$ & $\begin{array}{l}\text { Radicular } \\
\text { cyst }\end{array}$ & & & & & \\
\hline Palmitic acid & Saturated & 6.06 & 3.28 & 9.51 & 13.51 & $\begin{array}{l}\text { Increased } \\
{[29]}\end{array}$ & $\begin{array}{l}\text { Decrease the } \\
\text { infection [30] }\end{array}$ & $\begin{array}{l}\text { Weak antiviral } \\
\text { [31] }\end{array}$ & Increase [32] \\
\hline Stearic acid & & 5.99 & 4.40 & 7.54 & 11.70 & $\begin{array}{l}\text { Increased } \\
{[29]}\end{array}$ & NR & $\begin{array}{l}\text { Weak antiviral } \\
\text { [31] }\end{array}$ & $\begin{array}{l}\text { Increase [33, } \\
34]\end{array}$ \\
\hline Myristic acid & & 0.24 & 0.19 & 0.18 & 0.26 & $\begin{array}{l}\text { Increase }[35, \\
36]\end{array}$ & $N R$ & Antiviral [37] & Decrease [38] \\
\hline Octanoic acid & & 0.00 & 0.09 & 0.00 & 0.00 & NR & $N R$ & $\begin{array}{l}\text { Weak antiviral } \\
\text { [39] }\end{array}$ & No effect [40] \\
\hline L-lactic acid & & 0.00 & 1.48 & 0.00 & 0.00 & $\begin{array}{l}\text { Increased } \\
{[41]}\end{array}$ & $\begin{array}{l}\text { Ongoing } \\
\text { clinical trial } \\
{[42]}\end{array}$ & Antiviral [43] & $\begin{array}{l}\text { Decrease [44, } \\
45]\end{array}$ \\
\hline $\begin{array}{l}\text { Oleic acid } \\
\text { (monoun- } \\
\text { saturated } \\
\text { omega-9 fatty } \\
\text { acid) }\end{array}$ & $\begin{array}{l}\text { Monounsatu- } \\
\text { rated }\end{array}$ & 0.00 & 0.00 & 0.00 & 1.00 & $\begin{array}{l}\text { Increased [29, } \\
46]\end{array}$ & $\begin{array}{l}\text { Enhances } \\
\text { phagocytic } \\
\text { activity of } \\
\text { macrophages } \\
\text { [47] } \\
\text { Inhibit ACE-2 } \\
\text { receptors } \\
\text { [48] }\end{array}$ & $\begin{array}{l}\text { Antiviral [31, } \\
49]\end{array}$ & Decrease [50] \\
\hline $\begin{array}{l}\text { 17-Octadecy- } \\
\text { noic acid }\end{array}$ & & 0.35 & 0.00 & 0.00 & 0.00 & NR & $N R$ & $N R$ & No effect [51] \\
\hline $\begin{array}{l}\text { Petroselinic } \\
\text { acid }\end{array}$ & & 0.00 & 0.16 & 0.00 & 0.00 & NR & $N R$ & $\begin{array}{l}\text { Has binding } \\
\text { capacity } \\
\text { to RBD of } \\
\text { coronavirus } \\
\text { and to ACE-2 } \\
\text { [52] }\end{array}$ & $\begin{array}{l}\text { Anti-inflam- } \\
\text { matory [53] }\end{array}$ \\
\hline $\begin{array}{l}\text { 1-Nona- } \\
\text { decene }\end{array}$ & & 0.00 & 0.00 & 0.24 & 0.00 & NR & NR & $\mathrm{NR}$ & $N R$ \\
\hline
\end{tabular}


TMPRSS2 (PDB: 2OQ5) and S protein (PDB: 6MOJ) using Autodock Vina as docking engines.

\section{Treatment of mammalian cells with FAs}

HEK293 cells were cultured in DMEM/F-12 supplemented with $10 \%$ FBS, $1 \%$ penicillin-streptomycin and maintained at $37{ }^{\circ} \mathrm{C}$ and $5 \% \mathrm{CO}_{2}$. FA metabolites were dissolved in DMSO to prepare a stock of $1 \mathrm{mg} / \mathrm{ml}$ and then diluted with PBS to get the desired concentrations. The cells were treated with $10 \mathrm{ng} / \mathrm{ml}$ and $1000 \mathrm{ng} / \mathrm{ml}$ of palmitic acid, stearic acid, oleic acid, 17-octadecynoic acid, 1-nonadecene, and L-lactic acid for $48 \mathrm{~h}$. The cells were then harvested and kept at $-20{ }^{\circ} \mathrm{C}$ for downstream experiment.

\section{Quantitative real-time PCR (qRT-PCR)}

Clinical samples and treated HEK293 cells were used to quantify the gene expression of ACE-2, NRP-1 TMPRSS2, and IL-6transcripts. RNAs from homogenised samples and treated cells were isolated using RNeasy Mini Kit (QIAGEN, Germany), then reverse transcribed to cDNA using SuperScript ${ }^{\mathrm{TM}}$ III first-strand synthesis system (ThermoFisher Scientific, USA) according to manufacture instructions. Primer sequences are listed in Table 2. RT-PCR setup and cycling procedures were conducted using QuantStudio3 as previously described [54]. GAPDH was used as a housekeeping gene for normalization and the relative fold change was calculated using $2^{\wedge-(\Delta \Delta C t)}$

\section{Statistical analysis}

The collected data were organized in Excel worksheet and analysed using GraphPad (version 5.01). One-way or two-way analysis of variance (ANOVA) were used to analyse the quantity of the extracted metabolites and gene expression as indicated per each graph. The fold change of metabolites was calculated to compare the level of metabolites (area\%) between lesions and healthy control, or within a group. Oleic acid in healthy control was represented as a reference for calculating the approximate fold value for the other metabolites in all groups (Table 1).

\section{Results}

Expression of ACE-2, NRP-1 and TMPRSS2 genes were higher in healthy rather than periapical lesioned oral cavity, while IL- 6 gene expression was the reverse

To expect an estimated load of viral infection in oral lesions compared to healthy control, the expression of ACE-2, NRP-1, and TMPRSS2 genes in clinical samples was analysed. The results obtained indicated that ACE-2 and NRP-1 gene expression were significantly downregulated in periapical abscess, periapical granuloma, and radicular cyst when compared to healthy control $(P<0.001)$ (Fig. 1A, B). Additionally, the same pattern was observed for the expression of TMPRSS2 $\left(P^{<} 0.05\right)$ (Fig. 1C). These results indicate that the expression of critical genes required for viral infection was significantly reduced in oral lesions compared to healthy control. However, the expression of IL- 6 gene was upregulated significantly $\left(P^{<} 0.01\right)$ in periapical abscess and granuloma but insignificantly in radicular cyst compared to healthy control (Fig. 1D).

FAs of oral lesions were lower than those of healthy control Fatty acids (FAs) are one of the major metabolite classes that affect the microenvironment of the oral cavity and hence the infection rate $[60,61]$. FAs also play an important role in lipid synthesis required for viral replication $[17,18]$. Therefore, a comparative FAs analysis of oral lesions versus healthy oral cavity was conducted. The microenvironment of the identified FAs in oral lesions was compared to healthy control, and then correlated to the expression of receptors, TMPRSS2 activator enzyme, and IL-6 immunomodulator and hence to the SARS$\mathrm{CoV}-2$ infection loads in the oral cavity.

Qualitative and quantitative metabolomics analyses indicated that FAs were highly present in oral healthy control than in periapical oral lesions (Table 1). Palmitic acid, stearic acid, and myristic acid represented the most abundant saturated FAs identified in healthy control than in lesions. Literature's search showed that the aforementioned FAs are increased during coronavirus infection [29, 35, 36]. Reports also indicated that both palmitic and stearic acids have week antiviral activity [31]. Oleic acid, a monounsaturated FA,

Table 2 Primer sequences employed in this study

\begin{tabular}{llll}
\hline Gene & Forward $\left(\mathbf{5}^{\prime} \mathbf{-} \mathbf{3}^{\prime}\right)$ & Reverse $\left(\mathbf{5}^{\prime} \mathbf{-} \mathbf{3}^{\prime} \mathbf{)}\right.$ & Reference \\
\hline ACE2 & TCCGTCTGAATGACAACAGC & CACTCCCATCACAACTCCAA & [55] \\
NRP-1 & CCCAACAGCCTTGAATGCAC & ATTTCTAGCCGGTCGTAGCG & [56] \\
TMPRSS2 & GTCCCACTGTCTACGAGGT & CAGACGACGGGGTGGAAG & [57] \\
IL-6 & AGACAGCCACTCACCTCTTCAG & TTCTGCCAGTGCCTCTTTGCTG & [58] \\
GAPDH & GTCTCCTCTGACTTCAACAGCG & ACCACCCTGTTGCTGTAGCCAA & [59] \\
\hline
\end{tabular}



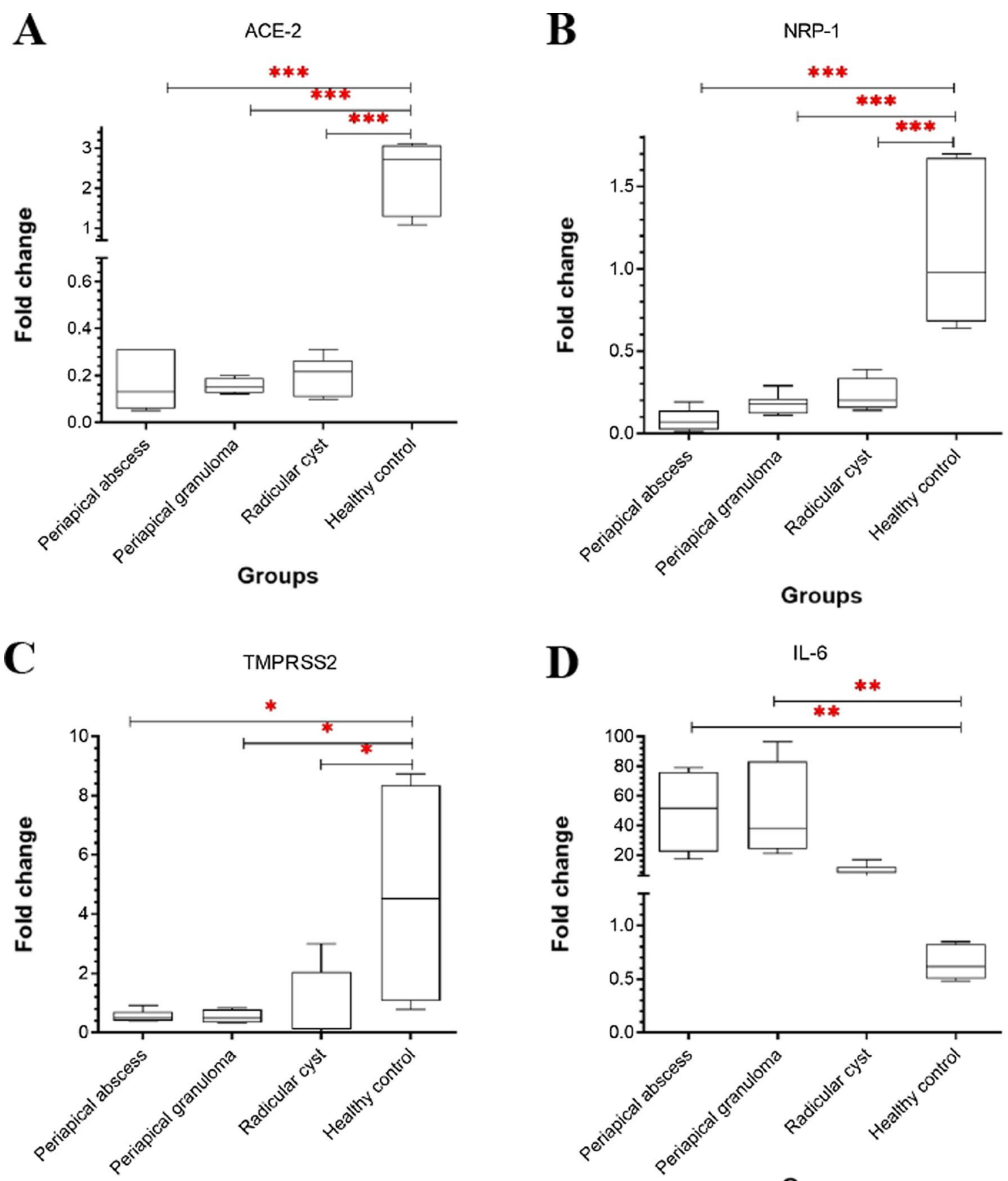

Groups

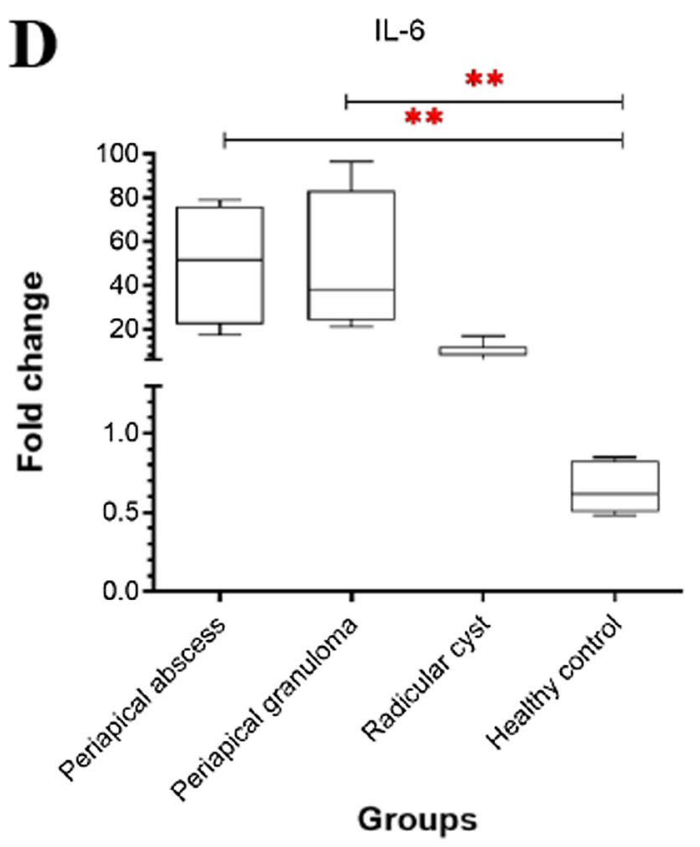

Fig. 1 Quantitative gene expression in periapical lesions and healthy controls. Identified gene expression was displayed as fold changes between groups. A ACE2. B NRP-1. C TMPRSS2. D IL-6. The data was analyzed using one-way analysis of variance (ANOVA), the statistical significance was calculated using Bonferroni's multiple comparisons test and the significance level indicated by asterisks $\left({ }^{*} P<0.05\right.$; ${ }^{* *} P<0.01:{ }^{* * *} P<0.001$; $\left.{ }^{* * * *} P<0.0001\right) . P$-value $<0.05$ was considered as significant. The data display the fold change in gene expression of 10 samples

has been also reported at a high level during coronavirus infection, while it is known to be accompanied by significant antiviral [31, 49] and anti-inflammatory effects [50]. Similarly, L-lactic acid, which is exclusively present in periapical granulomas, was also reported at a higher amount during coronavirus infection [41] and is known to exert antiviral [43] and anti-inflammatory effects $[44,45]$. 


\section{Docking study indicated that the identified FAs were less likely bind to target proteins}

To test the ability of the identified FAs to inhibit critical proteins in virus infection, molecular docking of FAs to ACE-2, TMPRSS2, and S protein was performed. The results showed a lower binding affinity of the identified FAs when compared to standards ligands including enalaprilat, benzamidine, and camostat (Table 3).

Table 3 Binding affinity of identified metabolites to ACE2, TMPSS2, and S protein

\begin{tabular}{llll}
\hline Metabolites & \multicolumn{3}{l}{ Binding affinity (Kcal/mol) } \\
\cline { 2 - 4 } & ACE2 & TMPRSS2 & S protein \\
\hline Palmitic acid & -5.7 & -4.5 & -5.5 \\
Stearic acid & -5.6 & -4.9 & -5.1 \\
Myristic acid & -5.6 & -4.2 & -5.2 \\
Oleic acid & -5.6 & -5.0 & -4.9 \\
17-Octadecynoic acid & -5.6 & -5.3 & -5.6 \\
Petroselinic acid & -6.0 & -5.1 & -5.4 \\
Octanoic acid & -4.8 & -4.5 & -4.6 \\
1-Nonadecene & -4.9 & -4.3 & -4.8 \\
L-(+)-lactic acid & -4.0 & -4.1 & -4.1 \\
Enalaprilat & -8.8 & - & - \\
Benzamidine & - & -5.6 & - \\
Camostat & - & -7.7 & - \\
Linoleic acid & - & - & -5.6 \\
\hline
\end{tabular}

FAs of healthy oral cavity enhanced the expression of ACE-2, NRP-1 and TMPRSS2 genes

To validate the importance of FAs in viral infection loads, HEK293 cells, employed as model cells endogenously expressing ACE-2, NRP-1, and TMPRSS2 were treated with selected FAs that were significantly differ between lesions and healthy control (Table 1). Two different concentrations of the tested metabolites, representing the difference between lesions and healthy control, were used. The results showed a significant increase in the gene expression of ACE-2 transcript in relation to the increase in concentration of palmitic acid $\left(P^{<} 0.01\right)$, stearic acid $\left(P^{<} 0.001\right)$, and 1-nonadecene $\left(P^{<} 0.001\right)$ (Fig. 2A). Other FA metabolites including oleic acid, 17-octadecynoic acid, and L-lactic acid insignificantly upregulate the expression of ACE-2 at the higher concentrations (Fig. 2A). Furthermore, the expression of NRP-1 gene was upregulated at higher concentrations of palmitic acid $\left(P^{<} 0.05\right)$ and 1-nonadecene $\left(P^{<} 0.01\right)$, and at a lower concentration of L-lactic acid $(P<0.05)$ (Fig. 2B). Insignificant expression of NRP-1 was observed when the cells were treated with stearic acid, oleic acid, and 17-octadecynoic acid (Fig. 2B). TMPRSS2 gene expression was also conducted and showed upregulation at higher concentrations of all tested FAs especially and significantly with palmitic acid $\left(P^{<} 0.05\right)$, stearic acid $\left(P^{<} 0.001\right)$, 1-nonadecene $\left(P^{<} 0.001\right)$, and L-lactic acid $\left(P^{<} 0.05\right)$ (Fig. $\left.2 \mathrm{C}\right)$. On the other hand, the expression of ACE-2, NRP-1 and TMPRSS2 was insignificantly affected when the cells were treated with higher concentrations of oleic acid or 17-octadecynoic in comparison to other FAs. This is in accordance with the data reported in Table 1.

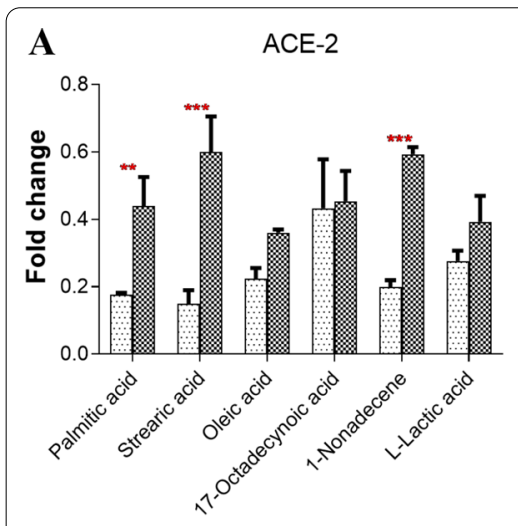

Metabolites treatment

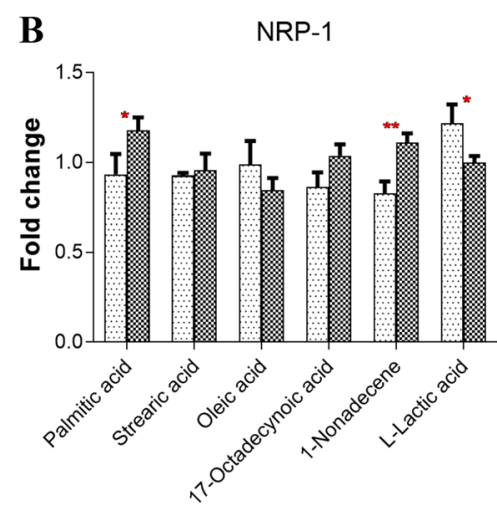

Metabolites treatment

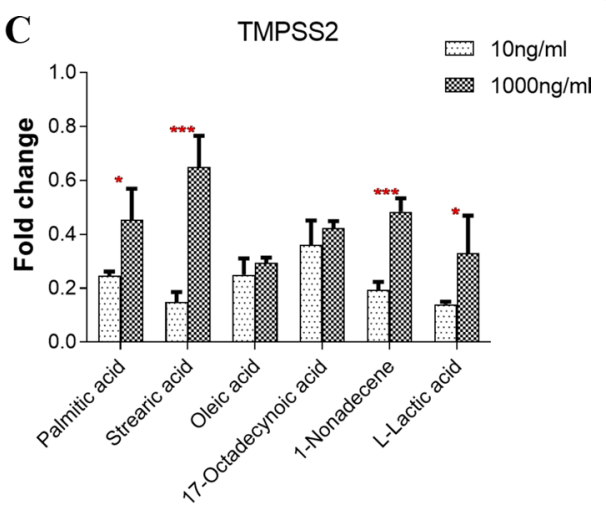

Metabolites treatment

Fig. 2 Quantitative gene expression of treated HEK293 cells. HEK293 cells were treated with two different concentrations of $10 \mathrm{ng} / \mathrm{ml}$ and $1000 \mathrm{ng} /$ $\mathrm{ml}$ of palmitic acid, stearic acid, oleic acid, 17-octadecynoic acid, 1-nonadecene, and L-lactic acid for 48 h. A ACE2. B NRP-1. CTMPSS2. Gene expression of the treated cells was normalised with its corresponding vehicle values. The data were analysed using two-way ANOVA, the statistical significance was calculated using Bonferroni's multiple comparisons test and the significance level indicated by asterisks $\left({ }^{*} P<0.05 ;{ }^{* *} P<0.01\right.$; $\left.{ }^{* * *} P<0.001 ;{ }^{* * *} P<0.0001\right)$. $P$-value $<0.05$ was considered as significant. The data display the fold change in gene expression in 3 replicas 
Collectively, higher concentrations of FAs particularly palmitic acid caused significant upregulation of the expression of ACE-2, NRP-1, and TMPRSS2 genes, while stearic acid significantly upregulated ACE-2 and TMPRSS2 gene expression. This is suggesting a higher viral load in the case of healthy compared to lesioned oral cavity (Fig. 3). The data were in accordance with those represented in Table 1 and Fig. 1A-C. Furthermore, 1-nonadecene significantly upregulated the gene expression of ACE-2, NRP-1, and TMPRSS2, indicating a possible higher viral load in radicular cysts compared to other periapical lesions but less than the healthy control. In reverse, inflammatory responses measured by IL- 6 gene expression was higher in periapical abscess and granuloma than radicular cysts and healthy control (Fig. 1D). On the other hand, oleic acid and L-lactic acid reduced the expression of NRP-1 gene.

\section{Discussion}

SARS-CoV-2 infection can be complicated by pathological conditions including those related to the entry of the virus at the oral cavity such as periapical lesions. Oral cavity expresses critical protein receptors such as ACE-2 and NRP-1 and enzymes such as TMPRSS2 required for viral entry and infection. Therefore, the impact of periapical lesions on the viral infection loads was studied in comparison to healthy oral cavity. Our results indicated that the expression of ACE-2, NRP-1 and TMPRSS2 was significantly reduced in oral lesions compared to healthy control. To investigate a reason for that, FAs microenvironment of the oral lesions compared to healthy control was studied since FAs play an important role in lipid rafts synthesis and hence receptors expression [18], in addition to their role in viral assembly [62] and host immunomodulatory effect. The results showed that FAs including palmitic acid, stearic acid, and myristic acid were highly presented in the oral healthy control than in periapical oral lesions. Furthermore, palmitic acid, and stearic acid-treated mammalian cells exhibited higher

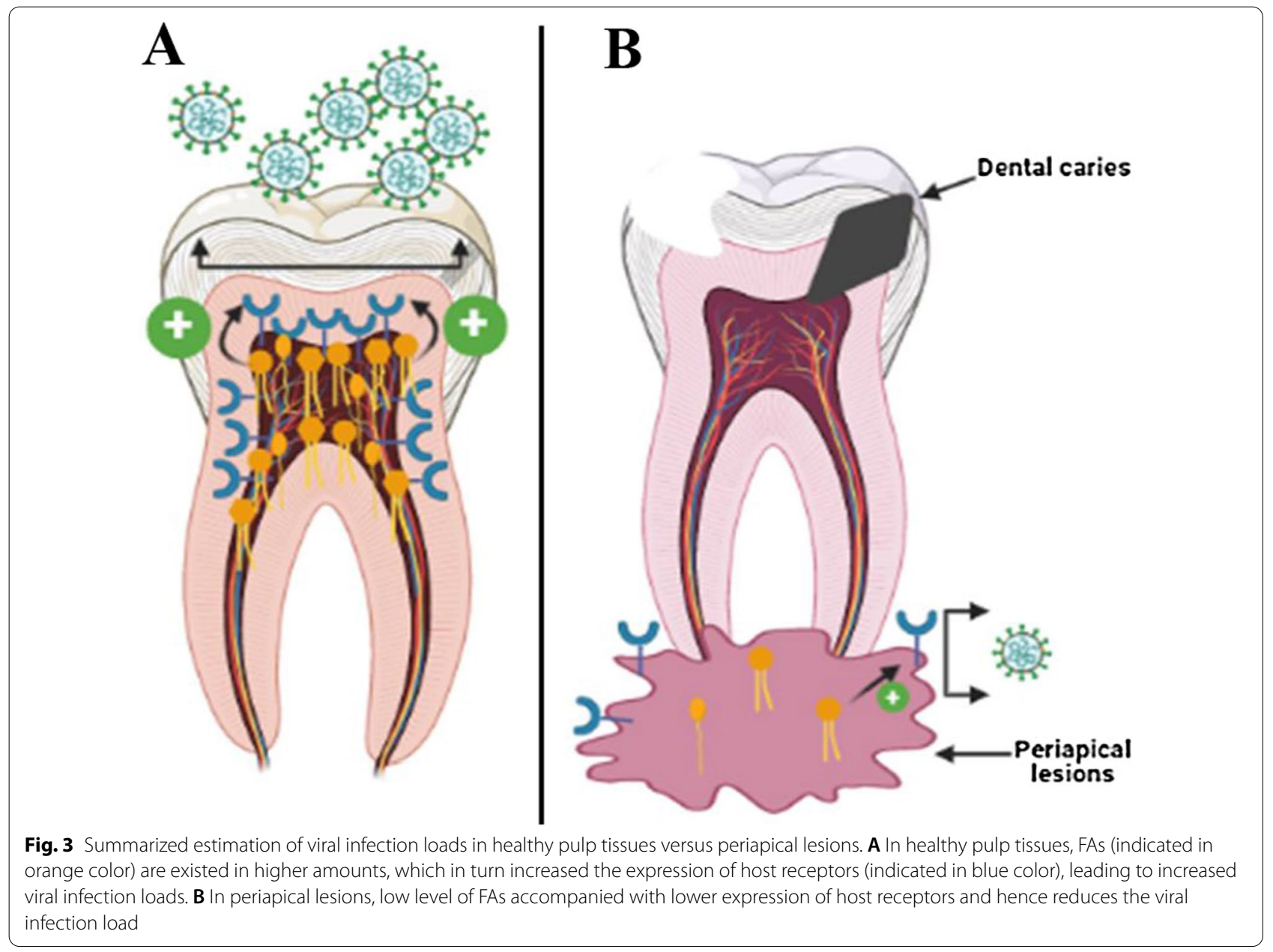


expression of ACE-2, NRP-1 and TMPRSS2, while oleic acid and L-lactic acid reduced the expression of NRP-1 and insignificantly affect the expression of ACE-2. This is in accordance with previously reported data on other coronaviruses as summarized in Table 1. On the other hand, there is a reverse correlation between the expression of IL-6 and SARS-CoV-2 receptors (Model represented in Fig. 4). These data estimated a higher viral infection load in healthy compared to periapical lesioned oral cavity. Therefore, an adverse and high cross-infectivity for the dental health workers may be expected during the dental procedures on healthy teeth in patients with COVID-19 infection. The results obtained can propose a special precautionary measure and safe environment to prevent the spread of disease during oral cavity-related procedures to be included in a general dental guideline $[63,64]$.

The expression of ACE-2, and NRP-1 in our study was higher in healthy pulp tissue than in periapical oral lesions, which is different than the results reported in the case of oral cancer, another oral pathological condition. ACE-2 [65] and NRP-1 [9] gene expression was reported at higher levels in oral cancer tissues. The difference with our results may be attributed to a variation in other factors including in particular inflammatory responses [66]. In accordance, our results in Fig. 1 showed a reverse correlation between IL- 6 and receptors expression, which is consistent with previously reported data on ACE-2 [67, 68] and NRP-1 [69] expression in relation to inflammatory responses. Besides, oleic acid and L-lactic acid are known immunomodulators [70] that can downregulate receptor expression. Similar to our results, the expression of TMPRSS2 gene is lower in the oral cavity of the head and neck squamous cell carcinoma [71], confirming that other factors such as inflammatory responses may be involved.

In this study, FAs levels were assessed in normal versus pathological oral cavity to predict the load of SARS$\mathrm{CoV}-2$ infection. FAs metabolism has been reported to be

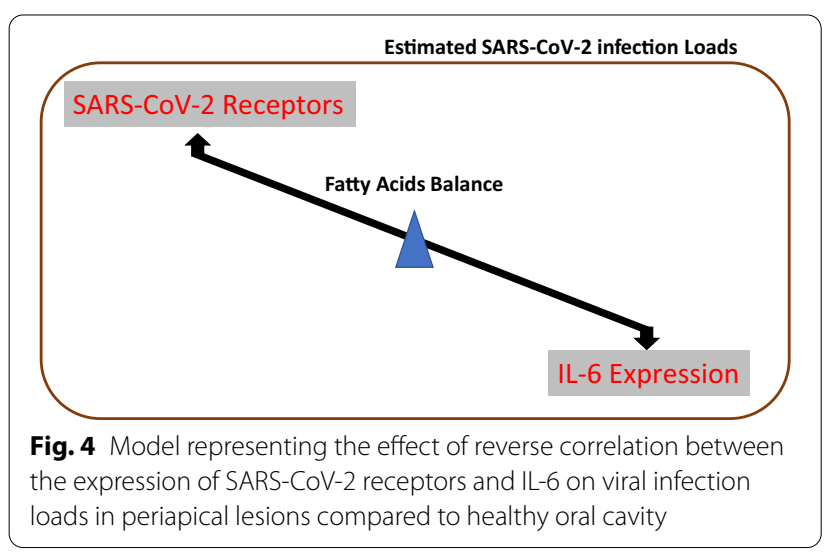

highly correlated to COVID-19 cases providing insights about their roles in either potentiating or reducing the infection [72]. Our results showed that saturated FAs such as palmitic and stearic acids were highly present in the healthy pulp tissue and were able to upregulate the expression of SARS-CoV-2 receptors in in vivo (Fig. 1) and in vitro (Fig. 2). These results may indicate their roles during the viral infection since they have been previously reported in high levels during coronavirus infection [29]. Both FAs are known to increase sphingolipids synthesis and the formation of lipid rafts and hence increase the expression of ACE-2 receptors [18]. Besides, both FAs possess weak antiviral activity [31] and proinflammatory effects [32-34].

In contrast, L-lactic acid was the exclusive metabolite detected in the periapical granuloma. Treatment of mammalian cells with L-lactic acid caused insignificant upregulation of ACE-2 (Fig. 2A) gene expression but significant downregulation of NRP-1 (Fig. 2B). Compared to healthy control, the expression of SARS-CoV-2 receptors and IL-6 in periapical granuloma remained significantly lower and higher, respectively (Fig. 1). This is indicating a downregulation of receptor expression due to inflammation, leading to an unfavourable binding condition for the virus in the periapical granuloma. In consistence, L-lactic acid has been reported at high level during coronavirus infection [41]. On the other side, L-lactic acid possesses antiviral [43] and anti-inflammatory effects [44, 45].

The effect of unsaturated FAs was different. 17-Octadecynoic acid was the only monounsaturated FA reported in periapical abscesses. The impact of 17-octadecynoic acid on coronavirus infection has never been reported. Mammalian cells treated with 17-octadecynoic acid caused insignificant effect on the expression of SARS$\mathrm{CoV}-2$ receptors. However, periapical abscesses showed a significant low expression level of SARS-CoV-2 receptors and higher expression of IL-6. These results indicated that periapical abscess is exposed to a lower viral infection load. On the other hand, 1-nonadecene has been identified for the first time as the exclusive unique unsaturated metabolite in the radicular cyst. Although there is a gap of knowledge regarding the biological activity of this metabolite, our study showed significant upregulation of SARS-CoV-2 receptors, which is inconsistent with the in vivo study (Fig. 1A-C). The difference in the expression of SARS-CoV-2 receptors between the in vitro (metabolite-treated mammalian cells) and in vivo (oral lesions) studies may be attributed to the effect of other factors such as the inflammatory responses (Fig. 1D). Furthermore, unsaturated FAs such as petroselinic acid [52], and oleic acid [31, 49] are known to have antiviral activity. 
Computationally, the binding affinity of the identified FAs to critical proteins and enzymes required for SARS$\mathrm{CoV}-2$ infection was low; hence, experimental testing still needs to be performed compared to linoleic acid. Linoleic acid has been reported as an excellent blocker of $\mathrm{S}$ protein by exerting conformational changes on $\mathrm{S}$ protein [73], although it showed a similar binding affinity to the FAs identified in this study.

In conclusion, oral lesions including periapical abscess, periapical granuloma, and radicular cyst showed lower expression of critical genes required for SARS-CoV-2 infection, predicting a lower viral infection load compared to healthy pulp tissues. The results obtained also indicated the superior effect of saturated FAs such as palmitic and stearic acids on the expression of the aforementioned genes. The balance between FAs in the oral cavity may be a detrimental factor for the expression of protein receptors and enzymes required for the viral infection. Shifting the balance towards saturated FAs such as palmitic and stearic acids increased the expression of viral receptors and hence the viral load as in the case of healthy pulp tissues. Furthermore, immunomodulators such as oleic and L-lactic acids can reduce the expression of SARS-CoV-2 receptors and hence the viral loads. For instance, a mouth preparation that can reduce the level of palmitic and stearic acids and with immunomodulatory effect can be employed as a preventive agent against viral infection.

\section{Acknowledgements}

Not applicable.

\section{Authors' contributions}

AM: acquisition of data, analysis, and interpretation of data, and drafting the article. RH: acquisition of data, analysis, and interpretation of data. TV: analysis and interpretation of data. $\mathrm{RH}$ : data interpretation, revising the article and funding acquisition. SS: conception and design of the study, drafting and revising the article, and funding acquisition. All authors read and approved the final manuscript.

\section{Funding}

The authors acknowledge the generous support from Sandooq Al-Watan and University of Sharjah (\# 133006) to SS and from University of Sharjah (CoV190308) to RH. The funding agencies provided the money required for the study and they have no role in designing the study, analyzing the data or writing the article.

\section{Availability of data and materials}

All data generated or analysed during this study are included in this published article.

\section{Declarations}

\section{Ethics approval and consent to participate}

All samples of periapical abscess, periapical granuloma, radicular cyst, and healthy pulp tissues were collected from Oral and Craniofacial Health Sciences Department, Medical Dental College, University of Sharjah. The informed consent was obtained from all patients with ethical approval registered at the Research Ethics Committee/University of Sharjah holding the reference number REC-18-12-17-02-S in 17/02/2019.

\section{Consent for publication}

Not applicable.

\section{Competing interests}

The authors declare that they have no competing interests.

\section{Author details}

${ }^{1}$ Research Institute of Medical and Health Sciences, University of Sharjah, Sharjah, UAE. ${ }^{2}$ Department of Physiology and Immunology, College of Medicine, Khalifa University, Abu Dhabi, UAE. ${ }^{3}$ Department of Clinical Sciences, College of Medicine, University of Sharjah, Sharjah, UAE. ${ }^{4}$ Department of Medicinal Chemistry, College of Pharmacy, University of Sharjah, Sharjah, UAE.

Received: 26 May 2021 Accepted: 21 October 2021

Published online: 08 November 2021

\section{References}

1. World Health Organization. Novel Coronavirus (2019-nCoV): situation report, 1. Geneva: World Health Organization; 2020.

2. Zhong M, Lin B, Pathak JL, Gao H, Young AJ, Wang X, Liu C, Wu K, Liu $M$, Chen J, et al. ACE2 and furin expressions in oral epithelial cells possibly facilitate COVID-19 infection via respiratory and fecal-oral routes. 2020;7(869):1-10

3. Xydakis MS, Dehgani-Mobaraki P, Holbrook EH, Geisthoff UW, Bauer C, Hautefort C, Herman P, Manley GT, Lyon DM, Hopkins C. Smell and taste dysfunction in patients with COVID-19. Lancet Infect Dis. 2020;20(9):1015-6.

4. Xu H, Zhong L, Deng J, Peng J, Dan H, Zeng X, Li T, Chen Q. High expression of ACE2 receptor of 2019-nCoV on the epithelial cells of oral mucosa. Int J Oral Sci. 2020;12(1):8.

5. Galicia JC, Guzzi PH, Giorgi FM, Khan AA. Predicting the response of the dental pulp to SARS-CoV2 infection: a transcriptome-wide effect crossanalysis. Genes Immun. 2020;21(5):360-3.

6. Wang H-B, Zhang H, Zhang J-P, Li Y, Zhao B, Feng G-K, Du Y, Xiong D, Zhong Q, Liu W-L. Neuropilin 1 is an entry factor that promotes EBV infection of nasopharyngeal epithelial cells. Nat Commun. 2015;6(1):1-13.

7. Lambert S, Bouttier M, Vassy R, Seigneuret M, Petrow-Sadowski C, Janvier S, Heveker N, Ruscetti FW, Perret G, Jones KS. HTLV-1 uses HSPG and neuropilin-1 for entry by molecular mimicry of VEGF165. Blood J Am Soc Hematol. 2009;113(21):5176-85.

8. Cantuti-Castelvetri L, Ojha R, Pedro LD, Djannatian M, Franz J, Kuivanen $\mathrm{S}$, van der Meer F, Kallio K, Kaya T, Anastasina M. Neuropilin-1 facilitates SARS-CoV-2 cell entry and infectivity. Science (New York, NY). 2020:370(6518):856-60.

9. Shahrabi-Farahani S, Gallottini M, Martins F, Li E, Mudge DR, Nakayama H, Hida K, Panigrahy D, D'Amore PA, Bielenberg DR. Neuropilin 1 receptor is up-regulated in dysplastic epithelium and oral squamous cell carcinoma. Am J Pathol. 2016;186(4):1055-64.

10. Olaso E, Lin HC, Wang LH, Friedman SL. Impaired dermal wound healing in discoidin domain receptor 2-deficient mice associated with defective extracellular matrix remodeling. Fibrogenesis Tissue Repair. 2011:4(1):5.

11. Koch S. Neuropilin signalling in angiogenesis. Biochem Soc Trans. 2012:40(1):20-5.

12. Zhang Y, Su J, Teng Y, Zhang J, Wang J, Li K, Yao L, Li X. Nrp1, a neuronal regulator, enhances DDR2-ERK-RunX2 cascade in osteoblast differentiation via suppression of DDR2 degradation. Cell Physiol Biochem. 2015;36(1):75-84.

13. Sijaona A, Luukko K, Kvinnsland IH, Kettunen P. Expression patterns of Sema3F, PlexinA4,-A3, Neuropilin1 and-2 in the postnatal mouse molar suggest roles in tooth innervation and organogenesis. Acta Odontol Scand. 2012;70(2):140-8.

14. Song Y, Liu X, Feng X, Gu Z, Gu Y, Lian M, Xiao J, Cao P, Zheng K, Gu $X$. NRP1 accelerates odontoblast differentiation of dental pulp stem cells through classical Wnt/ $\beta$-Catenin signaling. Cell Reprogram. 2017;19(5):324-30.

15. Bestle D, Heindl MR, Limburg H, Van Lam van T, Pilgram O, Moulton H, Stein DA, Hardes K, Eickmann M, Dolnik O, et al. TMPRSS2 and furin are both essential for proteolytic activation of SARS-CoV-2 in human airway cells. Life Sci Alliance. 2020;3(9):e202000786. 
16. Sakaguchi W, Kubota N, Shimizu T, Saruta J, Fuchida S, Kawata A, Yamamoto Y, Sugimoto M, Yakeishi M, Tsukinoki K. Existence of SARS-CoV-2 entry molecules in the oral cavity. Int J Mol Sci. 2020;21(17):6000.

17. Guinea R, Carrasco L. Effects of fatty acids on lipid synthesis and viral RNA replication in poliovirus-infected cells. Virology. 1991;185(1):473-6.

18. Alketbi EH, Hamdy R, El-Kabalawy A, Juric V, Pignitter M, A. Mosa K, Almehdi AM, El-Keblawy AA, Soliman SSM. Lipid-based therapies against SARS-CoV-2 infection. Rev Med Virol. 2021;31:e2214

19. Xu Y, Baylink DJ, Chen C-S, Reeves ME, Xiao J, Lacy C, Lau E, Cao H. The importance of vitamin d metabolism as a potential prophylactic, immunoregulatory and neuroprotective treatment for COVID-19. J Transl Med. 2020;18(1):322.

20. Blasco H, Bessy C, Plantier L, Lefevre A, Piver E, Bernard L, Marlet J, Stefic K, Benz-de Bretagne I, Cannet P, et al. The specific metabolome profiling of patients infected by SARS-COV-2 supports the key role of tryptophan-nicotinamide pathway and cytosine metabolism. Sci Rep. 2020;10(1):16824

21. Torabinejad M, Walton R. Periradicular lesions. In: Bakland LK, editor. Endodontics. 4th ed. Baltimore: Williams \& Wilkins; 1994. p. 439-64.

22. George N, Flamiatos E, Kawasaki K, Kim N, Carriere C, Phan B, Joseph R, Strauss S, Kohli R, Choi D, et al. Oral microbiota species in acute apical endodontic abscesses. J Oral Microbiol. 2016;8:30989.

23. Nekoofar MH, Namazikhah MS, Sheykhrezae MS, Mohammadi MM, Kazemi A, Aseeley Z, Dummer PM. pH of pus collected from periapical abscesses. Int Endod J. 2009;42(6):534-8.

24. Lanza RKI. Dental pulp stem cells. In: Lanza R, Klimanskaya I, editors. Essential stem cell methods. 1st ed. Amsterdam: Elesevier; 2009. p. 78.

25. Altaie AM, Venkatachalam T, Samaranayake LP, Soliman SSM, Hamoudi R. Comparative metabolomics reveals the microenvironment of common T-helper cells and differential immune cells linked to unique periapical lesions. Front Immunol. 2021;12(3500):1-24.

26. Mussano F, Ferrocino I, Gavrilova N, Genova T, Dell'Acqua A, Cocolin L, Carossa S. Apical periodontitis: preliminary assessment of microbiota by $16 \mathrm{~S}$ rRNA high throughput amplicon target sequencing. BMC Oral Health. 2018;18(1):55.

27. Soliman SSM, Alhamidi TB, Abdin S, Almehdi AM, Semreen MH, Alhumaidi RB, Shakartalla SB, Haider M, Husseiny MI, Omar HA. Effective targeting of breast cancer cells (MCF7) via novel biogenic synthesis of gold nanoparticles using cancer-derived metabolites. PLOS ONE. 2020;15(10):e0240156.

28. Semreen MH, Soliman SSM, Saeed BQ, Alqarihi A, Uppuluri P, Ibrahim AS. Metabolic profiling of Candida auris, a newly-emerging multi-drug resistant Candida species, by GC-MS. Molecules. 2019;24(3):399.

29. Barberis E, Timo S, Amede E, Vanella WV, Puricelli C, Cappellano G, Raineri D, Cittone MG, Rizzi E, Pedrinelli AR, et al. Large-scale plasma analysis revealed new mechanisms and molecules associated with the host response to SARS-CoV-2. Int J Mol Sci. 2020:21(22):8623.

30. El-Kurdi B, Khatua B, Rood C, Snozek C, Cartin-Ceba R, Singh VP, El-Kurdi B, Khatua B, Rood C, Snozek C, et al. Mortality from coronavirus disease 2019 increases with unsaturated fat and may be reduced by early calcium and albumin supplementation. Gastroenterology. 2020;159(3):1015-1018. e1014.

31. Thormar H, Isaacs CE, Brown HR, Barshatzky MR, Pessolano T. Inactivation of enveloped viruses and killing of cells by fatty acids and monoglycerides. Antimicrob Agents Chemother. 1987;31(1):27-31.

32. Zhou BR, Zhang JA, Zhang Q, Permatasari F, Xu Y, Wu D, Yin ZQ, Luo $D$. Palmitic acid induces production of proinflammatory cytokines interleukin-6, interleukin-1 $\beta$, and tumor necrosis factor-a via a NF-KBdependent mechanism in $\mathrm{HaCaT}$ keratinocytes. Mediators Inflamm. 2013:2013:530429.

33. Miao H, Chen L, Hao L, Zhang X, Chen Y, Ruan Z, Liang H. Stearic acid induces proinflammatory cytokine production partly through activation of lactate-HIF1a pathway in chondrocytes. Sci Rep. 2015;5(1):13092.

34. Bersch-Ferreira ÂC, Sampaio GR, Gehringer MO, Torres EAFDS, RossFernandes MB, da Silva JT, Torreglosa CR, Kovacs C, Alves R, Magnoni $C D$, et al. Association between plasma fatty acids and inflammatory markers in patients with and without insulin resistance and in secondary prevention of cardiovascular disease, a cross-sectional study. Nutr J. 2018;17(1):26
35. Troisi J, Cavallo P, Masarone M, Sepe I, Scala G, Campiglia P, De Caro F, Boccia G, Ciacci C, Poto S. Serum metabolomic profile of symptomatic and asymptomatic SARS-CoV-2 infected patients. Res Square. 2020.

36. Cai Y, Kim DJ, Takahashi T, Broadhurst DI, Yan H, Ma S, Rattray NJW, Casanovas-Massana A, Israelow B, Klein J, et al. Kynurenic acid may underlie sex-specific immune responses to COVID-19. Sci Signal. 2021;14(690):eabf8483.

37. Hilmarsson H, Traustason BS, Kristmundsdóttir T, Thormar H. Virucidal activities of medium- and long-chain fatty alcohols and lipids against respiratory syncytial virus and parainfluenza virus type 2: comparison at different pH levels. Adv Virol. 2007;152(12):2225-36.

38. Muralidharan J, Papandreou C, Sala-Vila A, Rosique-Esteban N, Fitó M, Estruch R, Angel Martínez-González M, Corella D, Ros E, Razquín C, et al. Fatty acids composition of blood cell membranes and peripheral inflammation in the PREDIMED study: a cross-sectional analysis. Nutrients. 2019;11(3):576.

39. Darnell ME, Taylor DR. Evaluation of inactivation methods for severe acute respiratory syndrome coronavirus in noncellular blood products. Transfusion. 2006;46(10):1770-7.

40. Yoshida H, Miura S, Kishikawa H, Hirokawa M, Nakamizo H, Nakatsumi RC, Suzuki $H$, Saito H, Ishii H. Fatty acids enhance GRO/CINC-1 and Interleukin-6 production in rat intestinal epithelial cells. J Nutr. 2001;131(11):2943-50.

41. Lu Y, Sun K, Guo S, Wang J, Li A, Rong X, Wang T, Shang Y, Chang W, Wang S. Early Warning Indicators of Severe COVID-19: A Single-Center Study of Cases From Shanghai, China. Front Med. 2020;7:432.

42. Sung A, Wischmeyer P. A randomized trial of the effect of lactobacillus on the microbiome of household contacts exposed to COVID-19. Duke University; 2021.

43. Virucidal activity of Jungbunzlauer L(+)-Lactic Acid. https://www.jungb unzlauer.com/en/news/view/virucidal-activity-of-jungbunzlauer-l-lacticacid.html.

44. Xu G, Jiang J, Wang M, Li L, Su J, Ren X. Lactic acid reduces LPS-induced TNF- $a$ and IL-6 mRNA levels through decreasing IKBa phosphorylation. J Integr Agric. 2013;12(6):1073-8.

45. Caslin H, Abebayehu D, Qayum AA, Hoeferlin LA, Chalfant CE, Ryan JJ. Lactic acid suppresses LPS-induced cytokine production in vitro and in vivo. J Immunol. 2017;198(Suppl 1):222.216-222.216.

46. Yan B, Chu H, Yang D, Sze KH, Lai PM, Yuan S, Shuai H, Wang Y, Kao RY, Chan JF, et al. Characterization of the lipidomic profile of human coronavirus-infected cells: implications for lipid metabolism remodeling upon coronavirus replication. Viruses. 2019;11(1):73.

47. Das UN. Can bioactive lipids inactivate coronavirus (COVID-19)? Arch Med Res. 2020;51(3):282-6.

48. Goodfriend TL, Ball DL. Fatty acid effects on angiotensin receptors. J Cardiovasc Pharmacol. 1986;8(6):1276-83.

49. Marwah A, Marwah P. Coronavirus (COVID-19): A protocol for prevention, treatment and control. J Appl Nat Sci. 2020;12:119-23.

50. Baer DJ, Judd JT, Clevidence BA, Tracy RP. Dietary fatty acids affect plasma markers of inflammation in healthy men fed controlled diets: a randomized crossover study. Am J Clin Nutr. 2004;79(6):969-73.

51. Liu S, Xie Z, Zhao Q, Pang H, Turk J, Calderon L, Su W, Zhao G, Xu H, Gong $M C$, et al. Smooth muscle-specific expression of calcium-independent phospholipase A2 $\beta$ (iPLA2 $\beta$ ) participates in the initiation and early progression of vascular inflammation and neointima formation. J Biol Chem. 2012;287(29):24739-53.

52. Goc A, Niedzwiecki A, Rath M. Polyunsaturated $\omega-3$ fatty acids inhibit ACE2-controlled SARS-CoV-2 binding and cellular entry. Sci Rep. 2021;11(1):5207.

53. Malnoe ABM, Fay L. Use of petroselinic acid for the treatment of inflammations of superficial tissues. Societe des Produits Nestle SA; 1997.

54. Oh SH, Jang CS. Development and validation of a real-time PCR based assay to detect adulteration with corn in commercial turmeric powder products. Foods (Basel, Switzerland). 2020;9(7):882.

55. Ratajczak MZ, Bujko K, Ciechanowicz A, Sielatycka K, Cymer M, Marlicz W, Kucia M. SARS-CoV-2 entry receptor ACE2 is expressed on very small CD45(-) precursors of hematopoietic and endothelial cells and in response to virus spike protein activates the NIrp3 inflammasome. Stem Cell Rev Rep. 2021;17(1):266-77.

56. Matkar PN, Singh KK, Rudenko D, Kim YJ, Kuliszewski MA, Prud'homme GJ, Hedley DW, Leong-Poi H. Novel regulatory role of neuropilin-1 in 
endothelial-to-mesenchymal transition and fibrosis in pancreatic ductal adenocarcinoma. Oncotarget. 2016;7(43):69489-506.

57. Suzuki T, Itoh Y, Sakai Y, Saito A, Okuzaki D, Motooka D, Minami S, Kobayashi T, Yamamoto T, Okamoto T et al. Generation of human bronchial organoids for SARS-CoV-2 research. bioRxiv : the preprint server for biology. 2020.2020.2005.2025.115600.

58. Balint B, Yin H, Nong Z, Arpino JM, O'Neil C, Rogers SR, Randhawa VK, Fox SA, Chevalier J, Lee JJ, et al. Seno-destructive smooth muscle cells in the ascending aorta of patients with bicuspid aortic valve disease. EBioMedicine. 2019;43:54-66.

59. Nabokina SM, Inoue K, Subramanian VS, Valle JE, Yuasa H, Said HM. Molecular identification and functional characterization of the human colonic thiamine pyrophosphate transporter. J Biol Chem. 2014;289(7):4405-16.

60. Halczy-Kowalik L, Drozd A, Stachowska E, Drozd R, Żabski T, Domagała W. Fatty acids distribution and content in oral squamous cell carcinoma tissue and its adjacent microenvironment. PLoS ONE. 2019;14(6):e0218246-e0218246.

61. Bhaskaran N, Quigley C, Paw C, Butala S, Schneider E, Pandiyan P. Role of short chain fatty acids in controlling $\mathrm{T}(\mathrm{regs})$ and immunopathology during mucosal infection. Front Microbiol. 1995:2018:9.

62. Tanner JE, Alfieri C. The fatty acid lipid metabolism nexus in COVID-19. Viruses. 2021;13(1):90.

63. Cervino G, Fiorillo L, Surace G, Paduano V, Fiorillo MT, De Stefano R, Laudicella R, Baldari S, Gaeta M, Cicciù M. SARS-CoV-2 persistence: data summary up to Q2 2020. Data. 2020;5(3):81.

64. Cervino G, Oteri G. COVID-19 pandemic and telephone triage before attending medical office: problem or opportunity? Medicina (Kaunas). 2020;56(5):250.

65. Chauhan A, Ghoshal S, Pal A. Increased susceptibility of SARS-CoV2 infection on oral cancer patients; cause and effects: an hypothesis. Med Hypotheses. 2020;144:109987-109987.
66. Medina-Enríquez MM, Lopez-León S, Carlos-Escalante JA, Aponte-Torres Z, Cuapio A, Wegman-Ostrosky T. ACE2: the molecular doorway to SARSCoV-2. Cell Biosci. 2020;10(1):148.

67. de Lang A, Osterhaus AD, Haagmans BL. Interferon-gamma and interleukin-4 downregulate expression of the SARS coronavirus receptor ACE2 in Vero E6 cells. Virology. 2006;353(2):474-81.

68. Yao Y, Wang H, Liu Z. Expression of ACE2 in airways: Implication for COVID-19 risk and disease management in patients with chronic inflammatory respiratory diseases. Clin Exp Allergy. 2020;50(12):1313-24.

69. Weiss JM, Bilate AM, Gobert M, Ding Y, Curotto de Lafaille MA, Parkhurst $\mathrm{CN}$, Xiong H, Dolpady J, Frey AB, Ruocco MG, et al. Neuropilin 1 is expressed on thymus-derived natural regulatory $T$ cells, but not mucosagenerated induced Foxp3+T reg cells. J Exp Med. 2012;209(10):1723-42.

70. Sam QH, Ling H, Yew WS, Tan Z, Ravikumar S, Chang MW, Chai LYA. The divergent immunomodulatory effects of short chain fatty acids and medium chain fatty acids. Int J Mol Sci. 2021;22(12):6453.

71. Sacconi A, Donzelli S, Pulito C, Ferrero S, Spinella F, Morrone A, Rigoni M, Pimpinelli F, Ensoli F, Sanguineti G, et al. TMPRSS2, a SARS-CoV-2 internalization protease is downregulated in head and neck cancer patients. J Exp Clin Cancer Res. 2020;39(1):200.

72. Ayres JS. A metabolic handbook for the COVID-19 pandemic. Nat Metab. 2020;2(7):572-85.

73. Toelzer C, Gupta K, Yadav SKN, Borucu U, Davidson AD, Kavanagh Williamson M, Shoemark DK, Garzoni F, Staufer O, Milligan R, et al. Free fatty acid binding pocket in the locked structure of SARS-CoV-2 spike protein. Science (New York, NY). 2020;370(6517):725-30.

\section{Publisher's Note}

Springer Nature remains neutral with regard to jurisdictional claims in published maps and institutional affiliations.
Ready to submit your research? Choose BMC and benefit from:

- fast, convenient online submission

- thorough peer review by experienced researchers in your field

- rapid publication on acceptance

- support for research data, including large and complex data types

- gold Open Access which fosters wider collaboration and increased citations

- maximum visibility for your research: over $100 \mathrm{M}$ website views per year

At BMC, research is always in progress.

Learn more biomedcentral.com/submissions 